\title{
Front gardens to car parks: Changes in garden permeability and effects on flood regulation
}

\author{
Jennifer R. Warhurst a,1, Katherine E. Parks a, Lindsay McCulloch ${ }^{\text {b,2 }}$, Malcolm D. Hudson ${ }^{\mathrm{a}, *}$ \\ a Centre for Environmental Sciences, Faculty of Engineering and the Environment, University of Southampton, Hampshire SO17 1BJ, United Kingdom \\ b Southampton City Council, Civic Centre, Southampton, Hampshire SO14 7LY, United Kingdom
}

\section{H I G H L I G H T S}

- Front gardens in urban areas have seen a change in land cover.

- This change is a shift from permeable to impermeable surfaces, for car parking.

- This amounts to an average of $22.47 \%$ of land area, over a twenty year period.

- Meanwhile the required attenuation storage volumes have increased by $26.23 \%$.

- Our study indicates an increase in flood risk in known flooding hotspots.

\section{A R T I C L E I N F O}

\section{Article history:}

Received 14 January 2014

Received in revised form 21 February 2014

Accepted 9 March 2014

Available online xxxx

Editor: Simon Pollard

\section{Keywords:}

Climate change

Ecosystem services

Flooding

Permeability

Flood regulation

Urban land use

\begin{abstract}
A B S T R A C T
This study addresses the consequences of widespread conversion of permeable front gardens to hard standing car parking surfaces, and the potential consequences in high-risk urban flooding hotspots, in the city of Southampton. The last two decades has seen a trend for domestic front gardens in urban areas to be converted for parking, driven by the lack of space and increased car ownership. Despite media and political attention, the effects of this change are unknown, but increased and more intense rainfall, potentially linked to climate change, could generate negative consequences as runoff from impermeable surfaces increases. Information is limited on garden permeability change, despite the consequences for ecosystem services, especially flood regulation. We focused on eight flooding hotspots identified by the local council as part of a wider urban flooding policy response. Aerial photographs from 1991, 2004 and 2011 were used to estimate changes in surface cover and to analyse permeability change within a digital surface model in a GIS environment. The 1, 30 and 100 year required attenuation storage volumes were estimated, which are the temporary storage required to reduce the peak flow rate given surface permeability. Within our study areas, impermeable cover in domestic front gardens increased by $22.47 \%$ over the 20 -year study period (1991-2011) and required attenuation storage volumes increased by $26.23 \%$ on average. These increases suggest that a consequence of the conversion of gardens to parking areas will be a potential increase in flooding frequency and severity - a situation which is likely to occur in urban locations worldwide.
\end{abstract}

(c) 2014 Elsevier B.V. All rights reserved.

\section{Introduction}

Domestic gardens are a key element of urban green space and are an integral part of urban environments (Gupta et al., 2012). Urban green space is open space within a city boundary with vegetation cover planted deliberately or inherited from pre-urbanisation vegetation

\footnotetext{
* Corresponding author. Tel.: +442380 594797.

E-mail addresses: Jennifer.warhurst@atkinsglobal.com (J.R. Warhurst), K.E.Parks@soton.ac.uk (K.E.Parks), Lindsay.McCulloch@southampton.gov.uk (L. McCulloch), mdh@soton.ac.uk (M.D. Hudson).

1 Present address: Atkins, Epsom Gateway, 2 Ashley Avenue, Epsom, Surrey KT18 5AL, United Kingdom. Tel.: + 441372726140

2 Tel.: +442380833000
}

(Jim and Chen, 2006), covering a mixture of landscape types including public parks, sports grounds and all natural areas inclusive of domestic gardens. Green space contributes to environmental regulation of, for example, atmospheric pollution, flooding, and urban temperature extremes; although in the UK there is generally a lack of information surrounding the extent of these contributions (Pauleit et al., 2005; Perry and Nawaz, 2008).

Domestic gardens were, until recently, considered a connection with nature, a statement of care, a source of escapism and a social amenity (Freeman et al., 2012). Increasingly, UK front gardens have undergone changes from manicured permeable green spaces to impermeable surfaces (Smith et al., 2011), primarily because of the potential to provide parking facilities for road transport network access, in the face of 
increased car ownership and restrictions in access to on-street parking. As a result urban green space is perceived to be declining, curtailing city dwellers' connection with nature and reducing the ecosystem services they deliver (Freeman et al., 2012; Perry and Nawaz, 2008). Economic growth has driven this change with UK car ownership increasing from 14\% to 75\% between 1951 and 2010 (Department for Transport, 2011).

Although attention to domestic garden permeability change has grown, the rate of change has scarcely been quantified (Smith et al., 2011). Quantification is necessary as urban domestic garden coverage has been estimated to account for between 19\% and 27\% of urban green space in cities and there are numerous associated effects of permeability change, including ecosystem service losses and increased flood vulnerability (London Assembly Environment Committee, 2005; Gaston et al., 2005).

\subsection{Value of urban green space}

Despite increased parking demand, residential green space has a value that should not be forgotten (Perry and Nawaz, 2008). Residential green space is increasingly viewed as a 'luxury' item (Cameron et al., 2012); throughout the 2000s there has been a clear trend to a higher density of new housing, with smaller areas of green space (Dunse et al., 2013).

Green spaces are urban assets which contribute to city residents" quality of life, providing ecosystem services of increasing importance in the context of climate change such as flood regulation and temperature regulation (Farrugia et al., 2013). Ecosystem services, the terminology of which dates from the 1960s, are associated with ecological structures and processes which provide direct or indirect human benefits (Millennium Ecosystem Assessment, 2005). Urban green space, including domestic gardens provides a wide range ecosystem services, detailed as part of the UK National Ecosystem Assessment by Davies et al. (2011), yet little policy and legislation prevent their change to impermeable surfaces (Sayce et al., 2012).

\subsection{Flood vulnerability}

Surface water flooding is a hazard caused by heavy rainfall in urban environments (Kaźmierczak and Cavan, 2011). Impermeable surfaces increase surface water runoff and thus flood vulnerability (Kaźmierczak and Cavan, 2011), especially in urban city environments where they amass (Perry and Nawaz, 2008). Increased rainfall, potentially linked to climate change, is likely to result in more flooding events in these environments (Smith et al., 2009), and is a matter of current concern in the UK.

Recognition by local authorities (LAs) of flood vulnerability has improved with the development of surface water management plans (SWMPs - see below), so surface water flooding is a recognised risk in many UK cities (Kaźmierczak and Cavan, 2011; Perry and Nawaz, 2008). However, the question as to whether domestic garden permeability changes are intensifying the hazard has been the subject of limited research (Kaźmierczak and Cavan, 2011).

Green space presence reduces surface water flow rate and quantity through evapotranspiration, interception and the provision of temporary and permanent storage areas, enabling water to infiltrate the ground as opposed to entering drainage networks, which in the UK have been little modified since the Industrial Revolution, despite a six fold population increase (Ellis and D'Archy, 2002). Population growth has led to urbanisation, increased demand for urban living and affordable housing, typically with reduced garden sizes (Sayce et al., 2012). Furthermore, garden use is undergoing changes with the creation of dwellings in garden spaces, so-called "garden-grabbing" (Sayce et al., 2012). Urbanisation reduces garden size, and thus reduces urban green space, and alongside climate change presents a triple-edged sword for flood vulnerability and other ecosystem services (Perry and Nawaz, 2008).
An array of both 'quick fix' and long-term 'planning-based' solutions has been proposed and implemented to reduce flood vulnerability, both across the UK and globally (Swan, 2010). 'Quick fix' solutions are often preferred by financially constrained local councils and include in-sewer storage and sustainable urban drainage systems (SUDSs) (Swan, 2010). 'Planning-based' solutions include management of urban green space loss and extensive increases in drainage system capacity (Swan, 2010; Sayce et al., 2012). However, loss of urban green space, in the context of garden permeability change, despite the ecosystem services provided, is little considered or accounted for because it is largely unmanaged and unregulated (Perry and Nawaz, 2008).

\subsection{Policy and legislation}

The UK planning system has been accused of a slow response to the problem of garden permeability change (Boardman, 2003; Penning-Rowsell, 2001). This is thought to be mainly due to limited media interest which only began in 2004 (Perry and Nawaz, 2008), following the first report on the increasing proportion of impermeable domestic gardens in the UK prepared by the London Borough of Ealing (Healey, 2004). However, in light of increased housing demand and continuing urbanisation, the issue of garden permeability change has become politically contentious (Department for Communities and Local Government, 2010), especially due to the high rates of car ownership in Britain.

Domestic front or back gardens currently have no special status in planning law other than as part of private amenity space and are not classified as a land use in their own right (Department for Communities and Local Government, 2010; Sayce et al., 2012). and restrictions were eventually imposed in the National Planning Framework of 2012 (Sayce et al., 2012). However, the success of this is as yet unknown, and more local and national scale research is required to provide the evidence base for improved policy and legislation that will slow or halt the change of domestic gardens to impermeable surfaces (Perry and Nawaz, 2008).

\subsection{Case study: Southampton}

Southampton City's vulnerability to flooding was recognised by the 2011 SWMP (SCC, 2011). The SWMP was produced based on the requirements of the UK Floods and Water Management Act 2010 which established that unitary and county LAs would lead local flood management activities (SCC, 2011). A SWMP is a plan and report for surface water flooding, formulated through local partner and residential consultation, and analysis of historical and predicted flooding events. SWMP benefits include increased understanding of the location, likelihood and consequences of flooding, increased surface water flood planning, increased fulfilment of the requirements of the European Commission (2000), the Flood Risk Regulations (2009) and the Flood and Water Management Act (2010) and improved public engagement and understanding of surface water flooding.

The Southampton SWMP includes both fluvial (rising water levels in rivers and streams) and pluvial (overland flow generated by rainfall) flooding. The SWMP considered only surface water flooding (SCC, 2011): tidal and groundwater flooding were not considered as there are no high-risk groundwater areas within the city. Sixty flooding hotspots were included in the SWMP, including eight high-risk hotspots (Fig. 1), identified through the common risk rating approach (risk = severity * likelihood) using data from a variety of sources (Fig. 2) (SCC, 2011). A limitation with the Southampton SWMP is that the causes for flooding hotspots were not explicitly identified. Cause identification requires quantification and characterisation of land use change, along with estimation of the required attenuation storage volumes, and was a novel focus of this study.

Given the general increased public attention directed towards impermeable front gardens in relation to flood regulation, the limited evidence base calls for further research on this topic. Our aim is to quantify 


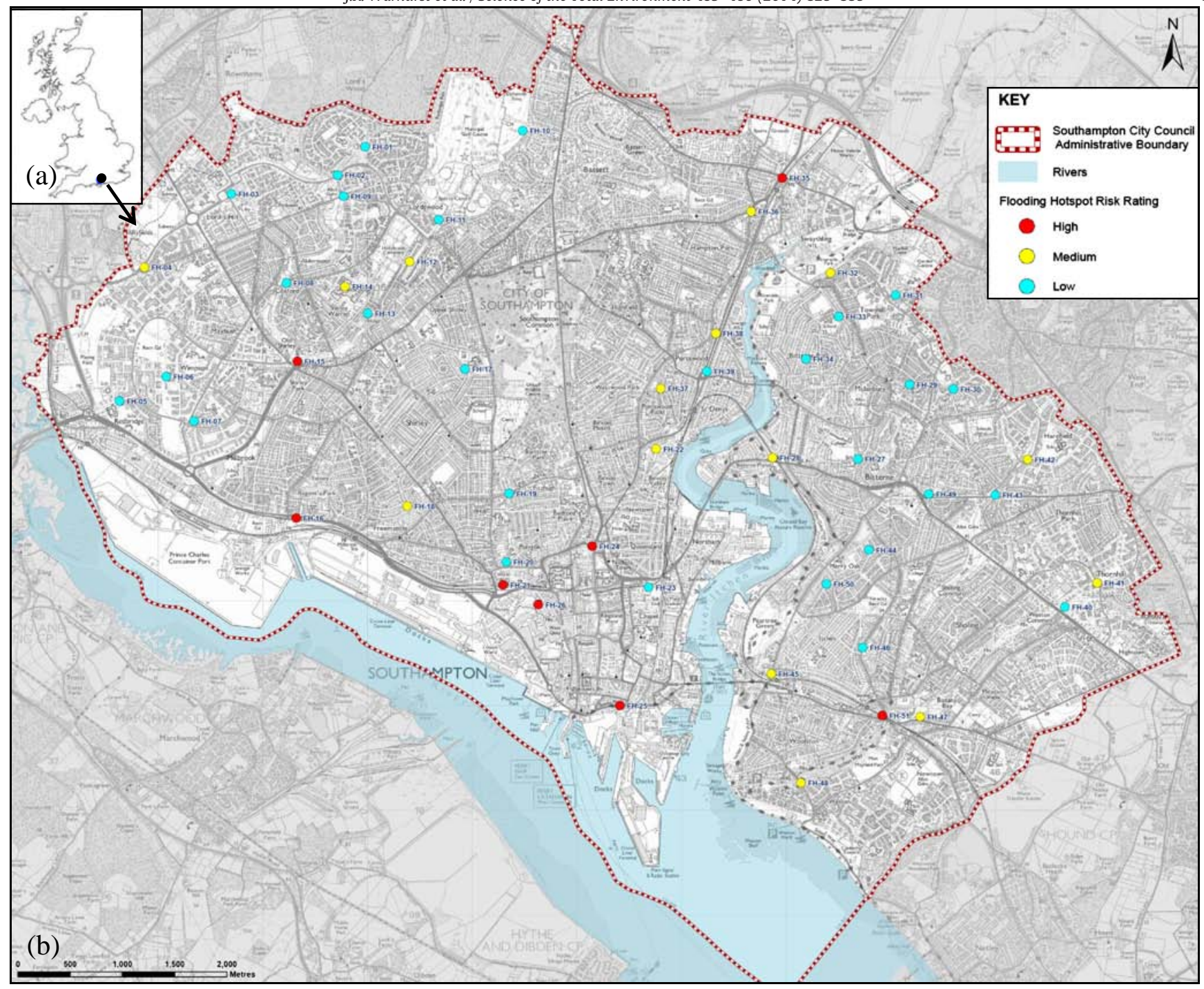

Fig. 1. The study area: (a) the location of Southampton and (b) the boundary of Southampton with the flooding hotspots.

permeability change in domestic front gardens (referred to henceforth as front gardens) in the high-risk flooding hotspots of Southampton, UK, and the effect on flood regulation. Southampton was selected given the presence of a detailed SWMP and SCC's expression of interest and concern about increased occurrence of impermeable front gardens.

\section{Methods}

There is no universal 'best approach' to hydrological modelling, it is considered that matching the approach to the study objectives, and using the simplest approach where numerous are available, is sufficient

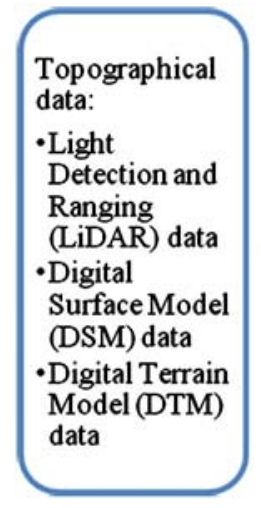

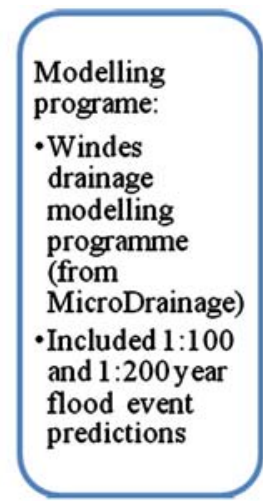

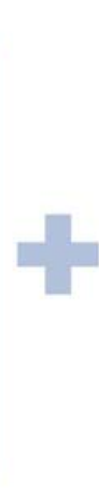

Surface water flood high-risk hotspots

Fig. 2. Southampton SWMP risk rating approach data. 
and is commonly used in land cover modelling (Perry and Nawaz, 2008). Based on simplicity and objectives, a simple mathematical model outlined in the Joint Defra/EA Flood and Coastal Erosion Risk Management R\&D Programme 2012 to estimate storage water volumes was used in this study.

\subsection{Study area}

Southampton is a city on the south coast of England (latitude $50.9339^{\circ} \mathrm{N}$ and longitude $1.3961^{\circ} \mathrm{W}$ ) (see introduction and Fig. 1), has a population of around 240,000 and covers $\sim 50 \mathrm{~km}^{2}$ (SCC, 2011). The eight high-risk flood hotspots, identified by the SWMP, were the subjects of this study, all having experienced historical flooding and with future flooding predicted (SCC, 2011).

\subsection{Use of aerial photographs and hydrological calculations}

The use of aerial photographs and hydrological modelling in the urban environment was first explored by Pauliet et al. (2005), whose research was based on randomly chosen sites, as opposed to modelling identified flooding hotspots. Modelling permeability change in known flooding hotspots has not, to our knowledge been the focus of any subsequent research and was our chosen approach. Incorporation of aerial photographs within a geographic information system (GIS) provides the ability to quantify different categories of land cover, making it highly suitable for domestic garden cover analysis (Perry and Nawaz, 2008).

\subsection{Drainage basins}

A digital elevation model (DEM) and a digital surface model (DSM) were available for Southampton from SCC. Since buildings and streets (objects), which account for much of Southampton's land cover, can block or facilitate water flow, the DSM was used for analysis because it incorporates the height values of the first surface on the ground, as opposed to ground level without objects. The DSM drainage basins for the high-risk hotspots were calculated in PCRaster v3 using "Iddcreate" (to create a local-drainage-direction map showing the drainage direction for each cell in the DSM) and "catchment" (to assign each cell in the DSM to its drainage basin) commands to produce ASCII files suitable for use in ArcGIS and MapInfo. The high-risk hotspot locations were entered into the model as polygons based on Southampton SWMP descriptions (SCC, 2011). The drainage basins are shown in Table 1, and Fig. 3.

Within each drainage basin, front gardens were identified by being adjacent to a residential dwelling, based on a combination of Ordnance Survey 2012 MasterMap (using EDINA Digimap Ordnance Survey Service), Google Earth and local knowledge sources, and were separated from back gardens by transport network access (Smith et al., 2011). Residential flats with areas of open space interspersed with parking facilities were identified as front gardens due to their transport network access.

\section{Table 1}

Size of the drainage basins $s^{\mathrm{a}}$.

\begin{tabular}{llr}
\hline High-risk hotspot number & High-risk hotspot name & Size $\left(\mathrm{m}^{2}\right)$ \\
\hline 1 & A33 & $12,060,000$ \\
2 & Queens Park & 493,300 \\
3 & Shirley Pond & $8,064,000$ \\
4 & Shoreburs Greenway & $6,077,000$ \\
5 & St. Andrews & 176,700 \\
6 & Train station & 7718 \\
7 & West Quay & 161,200 \\
8 & Wide Lane & $1,892,000$ \\
\hline
\end{tabular}

\footnotetext{
a The drainage basin for high-risk hotspot 3 was covered entirely by high-risk hotspot 1
} and as such was excluded from subsequent analysis to prevent double counting. Furthermore, the drainage basin for high-risk hotspot 6 did not cover any residential dwelling and as such did not feature in further analysis.

\subsection{Domestic front garden land cover categories}

Impermeable and permeable garden cover categories were defined based on site visits and aerial photograph resolutions (Table 2). The 'gravel' cover category was classed as permeable as under the 2008 amendment to the Town and Country Planning (General Permitted Development) Order it does not require planning permission.

\subsubsection{Calculation of domestic front garden land cover}

The total area of front gardens and garden cover categories was calculated using the 1991, 2004 and 2011 aerial photographs in MapInfo (version 9.5.1). A 20 year time frame with an intermediate point was used, 1991 being the oldest aerial photograph with a resolution high enough to classify garden cover whilst 2011 was the latest available at the time of analysis. Table 3 depicts the photographic specifications. SCC had georeferenced all aerial photographs onto the 2011 British Ordnance Survey MasterMap. Under the licence terms the aerial photographs could be used for analysis but not for display.

Polygons for the garden cover categories were created. The areas not covered by polygons were buildings, roads or amenity green spaces. Buildings and roads were easily identifiable. However, green space boundaries presented potential errors, although the SCC Park and Green Spaces Map (SCC, 2013) provided supporting data to verify areas of uncertainty.

Impermeable and permeable garden covers, where difficult to identify, were differentiated by a detailed analysis of the land cover pattern e.g. 'other vegetation' with a less uniform surface than lawn. To prevent data bias, where garden cover could not be identified a cautious approach was taken and it was classified as permeable ('unknown'). This approach was applied except where evidence implied an impermeable surface e.g. a reappearing concrete driveway on either side of shadow would be classified impermeable ('impermeable unknown'). These approaches mean that the total area of impermeable cover is probably underestimated. Bird et al. (2000) highlighted a further potential problem as areas of permeable cover which are used for parking can compact to the extent that they are effectively impermeable. Should it occur, surface water would likely run to an un-compacted permeable area and therefore does not represent a significant issue as surface water runoff will infiltrate (Bird et al., 2000). After classification, the extent of each land-cover type was calculated in $\mathrm{m}^{2}$.

\subsection{Hydrological calculations}

The Joint Defra/EA Flood and Coastal Erosion Risk Management R\&D Programme 2012 calculations were applied to the data collected to estimate required attenuation storage volumes given the permeability changes. The data required and the methodology for the calculations are available in Kellagher (2012); a summary of the calculation process is demonstrated in Fig. 4. This calculation process, although extensive, has been designed for investigating potential drainage network stress and urban runoff before permeability changes occur in planning as opposed to intricately designing drainage systems, and as such it has low mathematical complexity and data requirements, suiting the data collected (Kellagher, 2012). The main outputs of the calculations were 1 , 30 and 100 year required attenuation storage volumes, which is the temporary storage required to reduce the peak flow rate given surface permeability (Kellagher, 2012). The required attenuation storage volumes address the problem of additional runoff volumes caused by permeability changes, which alters flood vulnerability and regulation (Kellagher, 2012). The main limitation of this methodology is that the additional sensitivity of different garden covers is not addressed.

\subsection{Statistical analysis}

Transformations failed to parametrically conform the data collected; therefore analysis used non-parametric tests to assist with 


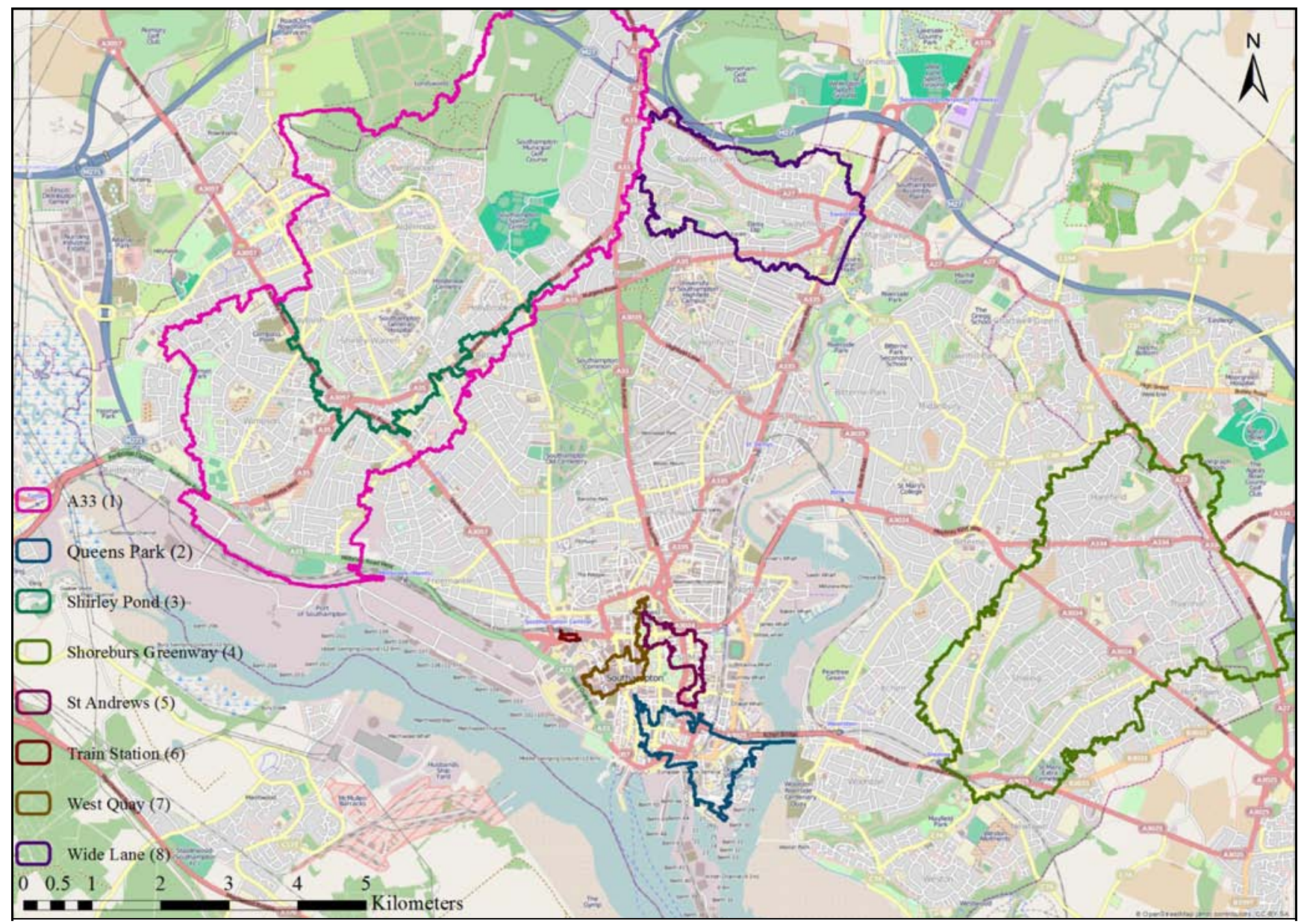

Fig. 3. Drainage basins for the eight high-risk flood hotspots on an Open Street Map background.

the investigation of permeability change and flood regulation. Comparisons to test the significant relationships in the data were made using the Chi-squared and Wilcoxon signed-rank statistical tests. Chi-squared was used to test for significant differences (for the total and within drainage basins) from the impermeable and permeable garden covers between 1991, 2004 and 2011 and between the 1991, 2004 and 2011 required attenuation storage volumes. Wilcoxon signed-rank was applied to the drainage basins, the percentage impermeable and permeable garden cover between 1991, 2004 and 2011 and between the required attenuation storage. The statistical analysis was performed using the IBM SPSS Statistics 21.0 software.

\section{Results}

\subsection{Drainage basin sample}

A sample threshold of $500,000 \mathrm{~m}^{2}$ (affecting high-risk hotspots 1 , 4 and 8 ) was applied to each drainage basin for feasibility reasons. For these high-risk hotspots a random sampling method to cover $150,000 \mathrm{~m}^{2}$ of the drainage basin was employed. A $1000 \mathrm{~m}^{2}$ grid and random number generation identified the $15\left(150,000 \mathrm{~m}^{2}\right)$ sample sites within high-risk hotspots 1,4 and 8. The sampling method was verified by comparing the cover classifications of $10 \%$ of highrisk hotspot 2 with the complete cover classifications for 2011. The cover was a $94.08 \%$ accurate representation of the complete site analysis.

\subsection{Domestic front garden cover 1991-2011}

There was no significant variation for the total domestic front garden cover within each drainage basin across 1991, 2004 and $2011\left(\chi^{2}(\mathrm{df} 2)=0.00793 ; \mathrm{P}>0.05\right)$. Total impermeable cover increased by $22.47 \%\left(15,584 \mathrm{~m}^{2}\right)$, from $46.27 \%$ in 1991 to $55.32 \%$ in 2011 , whereas total permeable cover decreased by $14.81 \%\left(13,109 \mathrm{~m}^{2}\right)$, from $53.73 \%$ in 1991 to $44.68 \%$ in 2011 (Figs. 4 \& 5; Table 4).

The general trend across the impermeable categories is an increase. However, the assumption that 'unknown' garden cover is permeable resulted in decreased impermeable cover between 2004 and 2011. Should the 'unknown' category be assumed impermeable the decrease does not occur, as the 2004 percentage cover follows an upward trend for impermeable cover (1991-2011, + 25.39\% change) and a downward trend for permeable cover (1991-2011, - 18.10\% change).

Over the study period and across all drainage basins, 'concrete' was the most extensive garden cover (40.49\% in 2011). 'Concrete' expanded its coverage between 1991 and 2011 by 9.53\%. The impermeable covers of brick and decking were not present in 1991 and developed to account for $6.29 \%$ and $<0.005 \%$ of garden cover respectively. 'Paving' accounted for the second largest area of impermeable cover, 7.86\% in 2011 and expanded its coverage by $22.40 \%$ between 1991 and 2011 . With the increased resolution and holistic quality of the aerial photographs, 'impermeable unknown' was not present after 1991.

The 'permeable unknown' category fluctuated up to a maximum of $2.49 \%$. The most extensive permeable cover was 'lawn' at $20.18 \%$. 'Lawn' experienced the greatest decline, 36.61\% between 1991 and 
Table 2

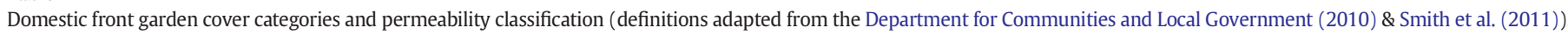

\begin{tabular}{|c|c|c|c|}
\hline $\begin{array}{l}\text { Garden } \\
\text { cover code }\end{array}$ & Garden cover category & $\begin{array}{l}\text { Permeability (impermeable (I)/ } \\
\text { permeable (P) classification) }\end{array}$ & Definition \\
\hline A & Brick & I & Small clay rectangular or square blocks \\
\hline B & Concrete & I & A flat smooth surface made through the coalescence of many substances e.g. stone and sand \\
\hline $\mathrm{C}$ & Decking & I & Wood, composite wood material or vinyl \\
\hline $\mathrm{D}$ & Impermeable unknown & I & $\begin{array}{l}\text { Evidence of a continued impermeable surface on either side of an area obscured by deep shadow, } \\
\text { poor photograph exposure or due to the photograph angle }\end{array}$ \\
\hline $\mathrm{E}$ & Paving & I & Large concrete or stone slabs laid in a uniform or irregular manner \\
\hline $\mathrm{F}$ & Other & I & $\begin{array}{l}\text { Recognisable land covers which do not fit into any of the broader categories e.g. swimming pools, } \\
\text { ponds and large contained compost heaps }\end{array}$ \\
\hline G & Gravel & $\mathrm{P}$ & Loose stone aggregate \\
\hline $\mathrm{H}$ & Lawn & $\mathrm{P}$ & A sparse, tall or closely mown grass/turf area \\
\hline I & Other vegetation & $\mathrm{P}$ & Small to medium sized ( $<2 \mathrm{~m}$ wide) herbaceous or woody plants \\
\hline $\mathrm{J}$ & Trees & $\mathrm{P}$ & A mature coniferous or deciduous woody species (canopy $\geq 2$ m wide) \\
\hline $\mathrm{K}$ & Unknown & $\mathrm{P}$ & Obscured by deep shadow, poor photograph exposure or due to the photograph angle \\
\hline
\end{tabular}

2011. 'Other vegetation' and 'trees' accounted for similar proportions of cover at $10.12 \%$ and $9.19 \%$ respectively, and both experienced downward trends throughout the study of $-15.08 \%$ and $-14.93 \%$ respectively. Total 'gravel' cover expanded by $3067.80 \%$ from $0.09 \%$ in 1991 to $2.70 \%$ in 2011.

Overall a difference was identified between the 1991 observed and the total impermeable coverage in 2004 and 2011 ( $\chi^{2}$ (df 2$)=$ 7.74; $\mathrm{P}<0.025$ ). Permeable cover had increased from that observed in 1991, but not significantly $\left(\chi^{2}(\mathrm{df} 2)=4.18 ; \mathrm{P}<0.1\right)$.

Between 1991 and 2011 there were significant differences between drainage basins in the observed total percentage impermeable cover (Wilcoxon signed-rank test: $\mathrm{z}=-10.19 ; \mathrm{P}<0.001)$; and in total percentage permeable cover type (Wilcoxon signed-rank test: $\mathrm{z}=$ $-12.24 ; \mathrm{P}<0.001$ ) (Fig. 6).

There was a significant difference between the expected average impermeable cover percentage change with no permeability change and that observed between 1991 and 2011 ( $\chi^{2}$ (df 5) = 843.78; $P<0.001$ ); and a significant difference between the expected average permeable cover percentage change and that observed between 1991 and 2011 $\left(\chi^{2}(\right.$ df 4$\left.)=-63963.27 ; \mathrm{P}<0.001\right)$.

The analysis of differences between the total covers of 'concrete', 'impermeable unknown', 'other', 'trees', 'lawn', 'other vegetation' and 'unknown' found a significant difference between the expected percentage change and that observed between 1991 and $2011\left(\chi^{2}\right.$ (df 2) $\geq 300$; $\mathrm{P}<0.001)$. 'Brick' and 'decking' were not present in 1991 and as a result the percentage change could not be calculated.

\subsection{Ground truthing}

Post-aerial photograph analysis, $10 \%$ of each drainage area's cover for 2011 was ground truthed to ensure reliability, with some potential for error because the fieldwork was carried out in February 2013. However, less than $0.005 \%$ of the domestic front gardens sampled had experienced changes in front garden cover and all changes were permeable to impermeable surfaces or 'gravel' supporting the trend of reduced vegetated cover.

\subsection{Hydrology}

It was not possible to distinguish between impermeable and permeable cover types in the hydrological calculations. Overall the total required attenuation storage volumes across all drainage basins increased over the study period (Fig. 7). Fig. 7 displays the 2004 outlier where the total impermeable cover was above that in 2011.

There were significant differences between each study year, between the total observed required attenuation storage volumes $(1,30$ and 100 years) in 2004 and 2011 and the expected required attenuation storage volumes (1, 30 and 100 years) with no permeability change (1991) $\left(1\right.$ year $\left(\chi^{2}(\mathrm{df} 2)=64.25 ; \mathrm{P}<0.001\right)$, 30 years $\left(\chi^{2}(\mathrm{df} 2)=\right.$ $151.02 ; \mathrm{P}<0.001)$ and 100 years $\left(\chi^{2}(\right.$ df 2$\left.\left.)=201.43 ; \mathrm{P}<0.001\right)\right)$.
Significant differences were demonstrated between drainage basins and 1,30 and 100 years of required attenuation storage volume, as expected given the differences in cover quantities within each drainage basin (Wilcoxon signed-rank test $\mathrm{z}=-3.724$ (across 1,30 and 100 years); $\mathrm{P}<0.001$ ). The percentage changes in required attenuation storage volumes for each drainage basin were equal across 1,30 and 100 years, a $213.50 \%$ increase between the 1 and 100 year volumes.

In summary, the percentage change in the required attenuation storage volumes between 1991 and 2011 across each drainage basin was significantly different from the average, with a $26.38 \%$ increase $\left(\chi^{2}(\right.$ df 5$\left.)=189.92 ; \mathrm{P}<0.001\right)$.

\section{Discussion}

In our study, the changes to impermeable and permeable surfaces in front gardens were assessed for the city of Southampton between 1991 and 2011. Our analysis focused on known flooding hotspots and is the first study to have taken such an approach with the methods we applied. Across the areas studied, an increase in impermeable surfaces was found. The permeability changes were shown to increase the required attenuation storage volumes, highlighting the importance of flood regulation. The implications of these findings are discussed under the following topics: permeability changes, flood regulation effects, overall impacts on urban green space and policy and legislation.

\subsection{Domestic front garden cover change 1991-2011}

In total $\sim 153,566 \mathrm{~m}^{2}$ of front garden was analysed, sampling within flooding hotspots - low and medium flood risk drainage basins were not considered. Although the total front garden cover in Southampton is unknown, the sampled analysis in this study accounted for $0.31 \%$ of the city's area. In other cities, front and back garden coverages account for $19-27 \%$ of the total area (London Assembly Environment Committee, 2005; Gaston et al., 2005). With the assumed mean garden coverage of $23 \%$, and half accounting for front gardens, the study is estimated to have analysed $2.67 \%$ of Southampton's front gardens. The sample method used was a $94.10 \%$ accurate representation of front gardens, however further analysis was not possible due to time constraints.

Impermeable front garden cover increased by 22.47\% between 1991 and 2011, a greater increase than observed in other studies. Perry and Nawaz (2008) found a 13\% increase in suburban Leeds over a 33 year

Table 3

Aerial photograph specifications.

\begin{tabular}{lllll}
\hline Year & Month & Day & $\begin{array}{l}\text { Black and white } \\
(B \& W) / \text { colour }(C)\end{array}$ & $\begin{array}{l}\text { Resolution } \\
(\mathrm{cm} \text { per pixel })\end{array}$ \\
\hline 1991 & Not available & Not available & B\&W & 37 \\
2004 & July & 29th & C & 12.5 \\
2011 & July & Multiple & C & 10 \\
\hline
\end{tabular}




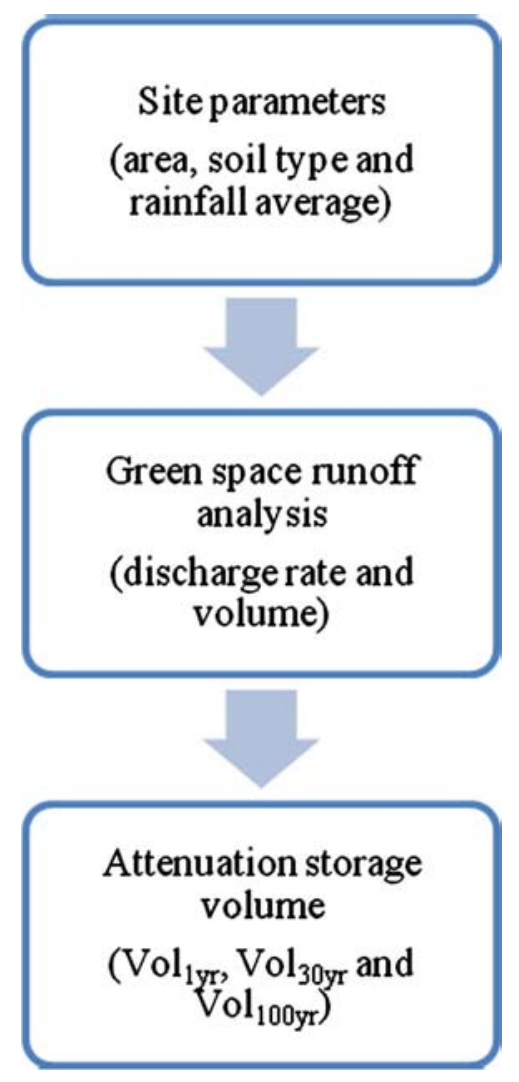

Fig. 4. Summarised hydrological calculation process.

study period (1971-2004) and Pauleit et al. (2005) described an 11\% increase across Southport over a 25 year study period (1975-2000). This study showed that in $201155.32 \%$ of front gardens were covered with impermeable surfaces, slightly lower than the $63 \%$ estimated for London in 2010 (Smith, 2010).

Concrete was the most widespread garden cover type in 2011, accounting for $40.49 \%$, presumably because it is the most cost efficient cover. Healey (2004) suggested that impermeable cover increases are based on numerous factors, including a desire for low maintenance gardens, increased cleanliness to the internal home environment, convenience, disabled access, reduced crime and vandalism and safety, and, in some cases, to avoid the costs associated with parking permits. The

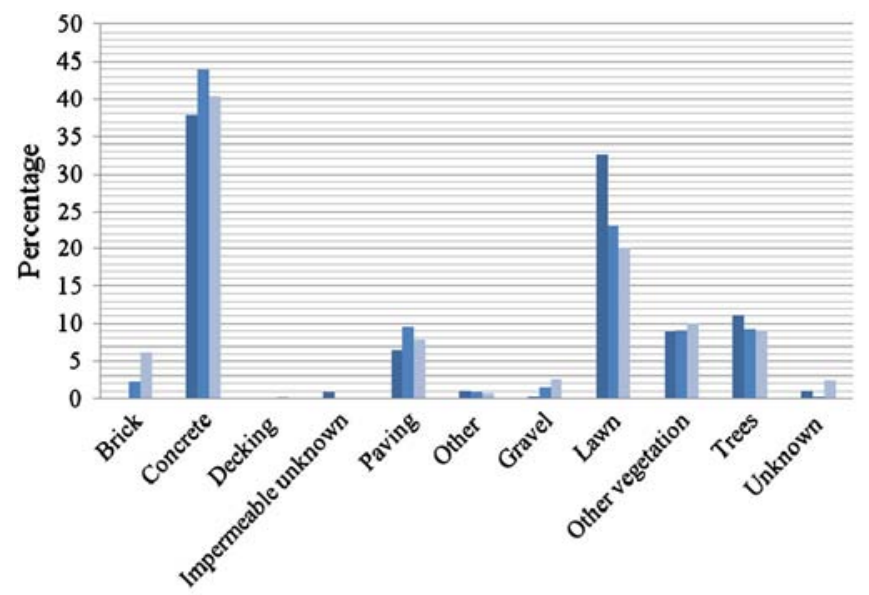

Domestic Front Garden Cover

=1991- $2004=2011$

Fig. 5. Total domestic front garden cover categories. latter factor is directly applicable to Southampton, there being areas requiring parking permits within all the drainage basins studied, especially for households with multiple cars. Furthermore, where on-street parking is the only viable option, parking pressures can be created. Historically, urban and suburban streets were predominantly developed to be two and a half cars in width, at a time when few owned cars, adding to present-day parking pressures. Many consider that on-street parking has an increased risk of damage to, or theft of, vehicles compared to offstreet parking and are drawn to the apparent benefits of impermeable front gardens for parking provision (Perry and Nawaz, 2008), although these greater risks are reported to be perceived but not evidence based (London Assembly Environment Committee, 2005).

Population growth and urbanisation are additional reasons for impermeable front gardens, factors increasing the demand for affordable housing, resulting in many large dwellings being converted into flats (Perry and Nawaz, 2008). This, combined with "garden grabbing" and increasing overall housing density, has increased parking requirements leading to more impermeable surface conversions (Sayce et al., 2012).

Demand for cars, and thus impermeable parking surfaces, is influenced by public transport accessibility and personal preference. It has been estimated that $77 \%$ of households in the UK have access to at least one car with a growth of 30\% predicted by 2020 (Leibling, 2008), suggesting that pressure on car parking space is likely to continue to increase, with further consequences for green space.

Furthermore, whilst front gardens were seen as a statement of care and a connection with nature, historically providing social status (Freeman et al., 2012; Smith et al., 2011), this may have been replaced by the displaying of cars (Perry and Nawaz, 2008). Exploring this social precedence was beyond the scope of this study but could be investigated further.

This study, unlike Perry and Nawaz (2008) and Smith (2010), found a 1.5\% decrease in impermeable cover between 2004 and 2011 despite an overall increase between 1991 and 2011; this was insignificant when 'unknown' garden cover was classed as impermeable, as in other studies such as Smith et al. (2011). The possibility of setting a minimum value for impermeable change was considered to reduce uncertainty in this study and as such 'unknown' was classed permeable.

The reasons for permeability change are applicable at a local scale but are also supported nationally by Royal Horticultural Society (2006) research. It was estimated that the North-East UK had the highest percentage (47\%) of front gardens that are more than three-quarters paved, the South-East had the fourth lowest (23\%), and London the lowest (14\%). Therefore the reasons for permeability change described here are as much, if not more so, applicable to other regions nationally. Growing media and political attention, primarily as a result of increased flooding, suggest that the issue will increase in importance and front gardens will be used as a flood regulation tool.

\subsection{Flood regulation}

Front gardens provide flood regulating services through evapotranspiration, infiltration and storage of precipitation; each of these reduces runoff quantities and speed, thus reducing pressure on drains (Kaźmierczak and Cavan, 2011). Bernatzky (1983) found that only $5-15 \%$ of falling precipitation in vegetated areas became runoff, compared to $60 \%$ in vegetation-free areas. Greater runoff increases the required attenuation storage volumes required to prevent flooding. This study found that the required attenuation storage volumes increased significantly by an average of $26.38 \%$ between 1991 and 2011. The likely consequence of this is an inability of the drainage networks associated with each basin to cope with precipitation events (Ellis and D'Archy, 2002).

There was an increase across the 1, 30 and 100 years required attenuation storage volumes which was expected, given that the methodology takes into account climate change (Kellagher, 2012). However, climate change is a variable factor and should levels of precipitation increase 
Table 4

Total changes in domestic front garden cover.

\begin{tabular}{|c|c|c|c|c|c|c|c|c|c|}
\hline \multicolumn{2}{|c|}{ Land cover code and type } & \multirow[t]{3}{*}{$\begin{array}{l}\text { Permeability (impermeable (I)/ } \\
\text { permeable (P) classification) }\end{array}$} & \multicolumn{6}{|c|}{$\begin{array}{l}\text { Area }\left(\mathrm{m}^{2}\right) \text { (to } 0 \text { d.p.) and percentage (\%) of total domestic front garden } \\
\text { cover (to } 2 \text { d.p.) }\end{array}$} & \multirow[t]{3}{*}{ \% Change 1991-2011 } \\
\hline & & & \multicolumn{2}{|l|}{1991} & \multicolumn{2}{|l|}{2004} & \multicolumn{2}{|l|}{2011} & \\
\hline & & & $\mathrm{m}^{2}$ & $\%$ & $\mathrm{~m}^{2}$ & $\%$ & $\mathrm{~m}^{2}$ & $\%$ & \\
\hline A & Brick & I & 0 & 00.00 & 3593 & 02.36 & 9615 & 06.29 & $\mathrm{~N} / \mathrm{A}$ \\
\hline B & Concrete & I & 56,772 & 37.87 & 67,048 & 44.04 & 62,180 & 40.49 & 09.53 \\
\hline C & Decking & I & 0.0 & 0.00 & 0 & 00.00 & 5 & 00.00 & N/A \\
\hline $\mathrm{D}$ & Impermeable unknown & I & 1188 & 00.79 & 0 & 00.00 & 0 & 00.00 & -100 \\
\hline $\mathrm{E}$ & Paving & I & 9863 & 06.58 & 14,541 & 09.55 & 12,073 & 07.86 & 22.40 \\
\hline $\mathrm{F}$ & Other & I & 1540 & 01.03 & 1328 & 00.87 & 1074 & 00.70 & -30.29 \\
\hline G & Gravel & $\mathrm{P}$ & 1310 & 00.09 & 2398 & 01.57 & 4150 & 02.70 & 3067.86 \\
\hline $\mathrm{H}$ & Lawn & $\mathrm{P}$ & 48,890 & 32.61 & 35,098 & 23.05 & 30,989 & 20.18 & 36.61 \\
\hline I & Other vegetation & $\mathrm{P}$ & 13,498 & 09.00 & 13,998 & 09.19 & 15,535 & 10.12 & 15.08 \\
\hline $\mathrm{J}$ & Trees & $\mathrm{P}$ & 16,593 & 11.07 & 14,062 & 09.24 & 14,116 & 09.19 & -14.93 \\
\hline K & Unknown & $\mathrm{P}$ & 1437 & 00.96 & 194 & 00.13 & 3829 & 02.49 & 166.50 \\
\hline \multicolumn{3}{|c|}{ Total impermeable } & 69,363 & 46.27 & 86,510 & 56.82 & 84,947 & 55.32 & 22.47 \\
\hline \multicolumn{3}{|c|}{ Total permeable } & 81,728 & 53.73 & 65,750 & 43.18 & 68,619 & 44.68 & -14.81 \\
\hline
\end{tabular}

beyond those currently predicted, required attenuation storage volumes will increase further (Smith et al., 2009). The 100 years required attenuation storage volume should be considered by LAs when considering drainage network renovations to ensure maximum lifespan, to prevent additional costs and to reduce surface water flooding.

Differences between the required attenuation storage volumes in different drainage basins were found. Housing variations have been suggested as an explanation for this (Pauleit and Duhme, 2000), with suburban lower density housing having threefold less storm water runoff than urban high density housing.

We have not identified any other studies which have considered required attenuation storage volumes in relation to surface changes in front gardens. However, Pauleit et al. (2005) and Perry and Nawaz
(2008) established that runoff increased with impermeable garden cover. Given the positive relationship between runoff and required attenuation storage volumes (Kellagher, 2012), it can be hypothesised that required attenuation storage volumes would have also increased in these studies.

Hollis (1975) predicted that a 30\% increase in impermeable cover increased flood peaks by $100 \%$. Therefore (assuming a linear relationship), the $22.47 \%$ impermeable increase in this study would suggest increases of the order of around 75\% in flood peaks across Southampton's drainage basins. Accurate flood peak calculations would be a useful extension to this study.

A further issue is that the creation of impermeable front gardens can reduce water quality (Deletic and Maksimovic, 1998). Impermeable
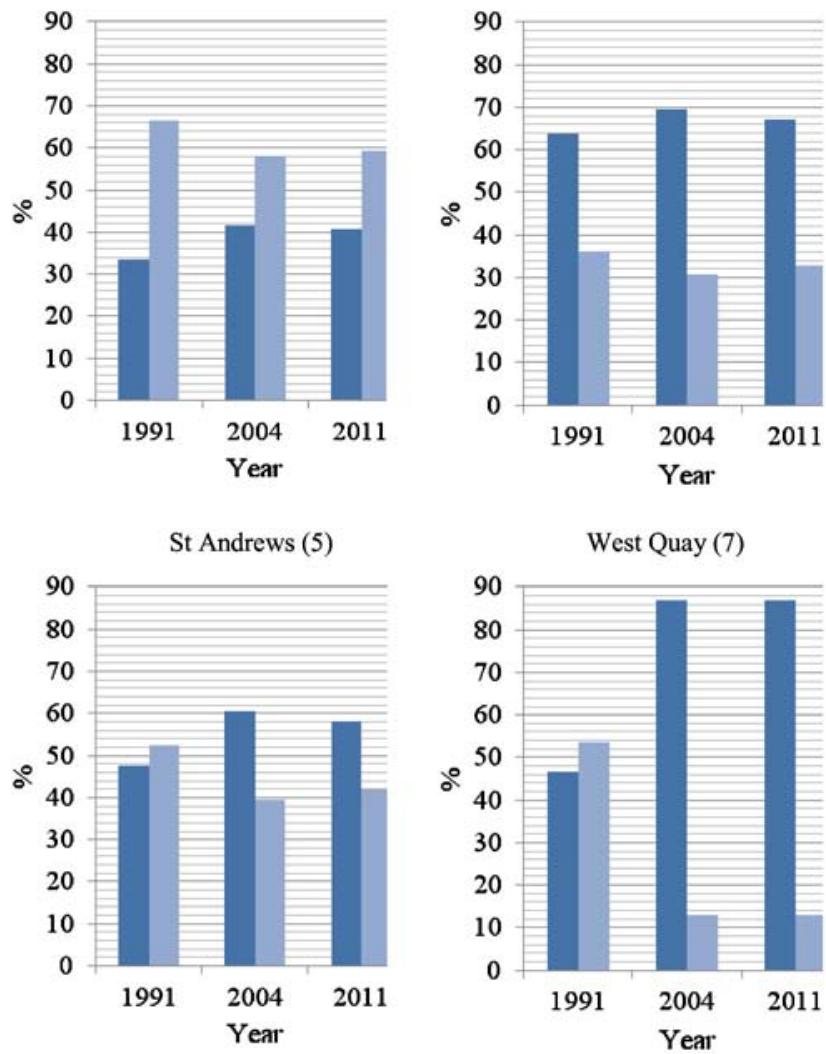

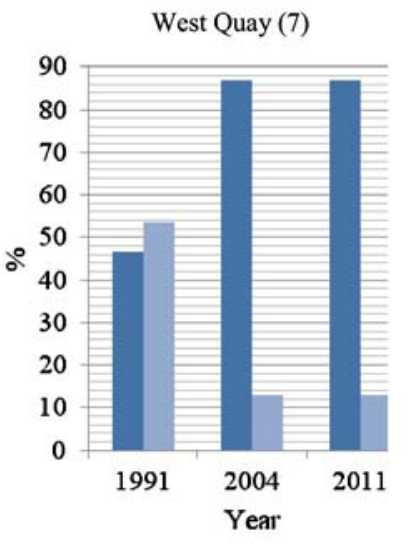

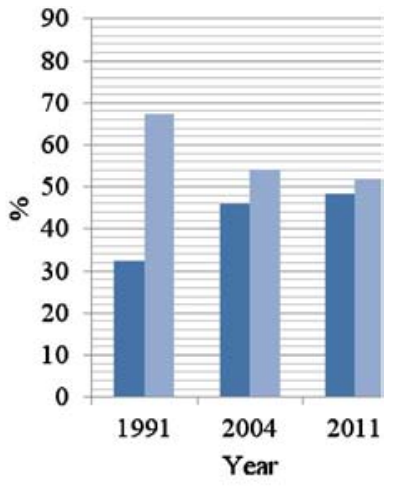

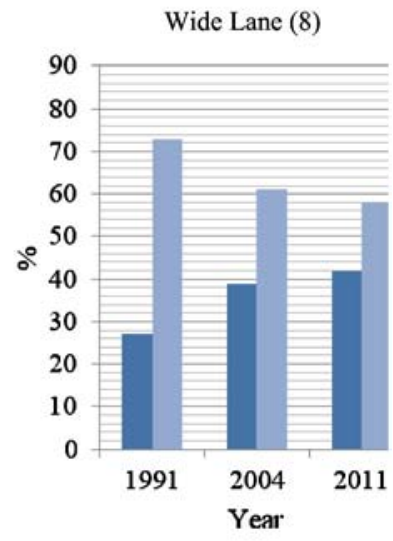

- Percentage Impermeable (\%)

= Percentage Permeable (\%)

Fig. 6. Impermeable and permeable domestic front garden cover categories across all drainage basins. 


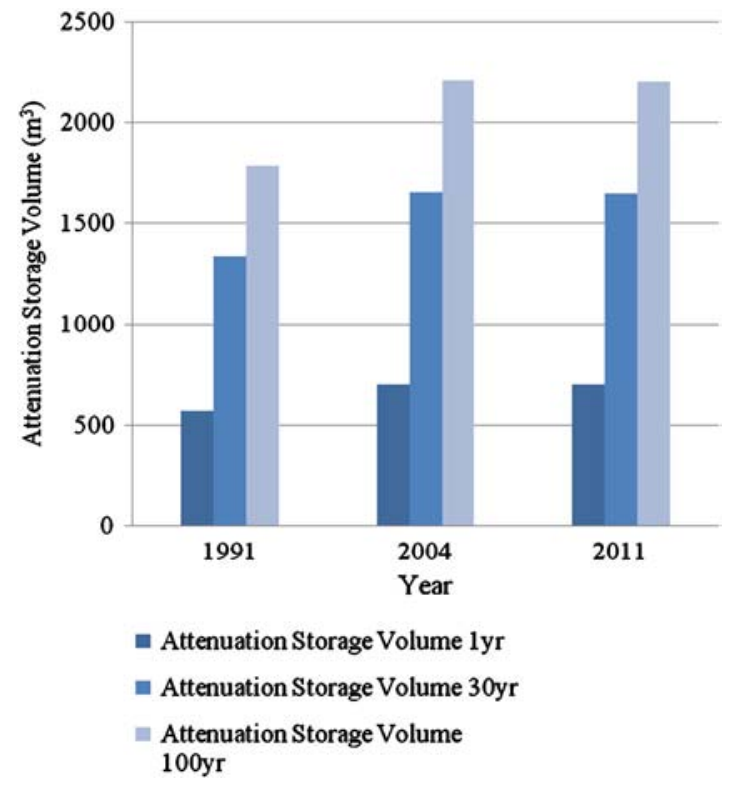

Fig. 7. Attenuation storage volume changes in 1991, 2004 and 2011 with impermeable domestic front cover change.

surface runoff typically includes anthropogenic pollutants and natural materials such as soil sediments (Deletic and Maksimovic, 1998) which are absorbed to a greater extent with vegetation. Increased impermeable front garden cover and the associated difficulties with flood regulation is a recognised problem within LAs but one that is hard to regulate (Kaźmierczak and Cavan, 2011). Should the changes illustrated in this study continue, the total number of low, medium and high-risk flooding hotspots across Southampton is likely to increase further.

\subsection{Importance to urban green space}

Domestic gardens can account for up to $26.8 \%$ of urban green space, according to an analysis of five major UK cities carried out by Loram et al. (2007); and with urbanisation and wealth growing globally their importance extends internationally (Goddard et al., 2010). For example domestic gardens account for $16 \%$ of total urban green space within Stockholm, Sweden (Colding et al., 2006), whilst in Dunedin, New Zealand, they account for 26\% (Mathieu et al., 2007). This study found a 14.81\% decline between 1991 and 2011 in permeable front gardens, resulting in an overall decrease in urban green space quantities. This is of high importance should similar decreases be occurring nationally and globally.

Vegetated gardens provide many urban green space ecosystem services, beyond flood regulation. Green space provides air filtration, where extensive leaf areas reduce air pollution (Givoni, 1991). The cover category of 'lawn' underwent the largest percentage change from permeable to impermeable. However, the limited air filtration capacity of lawns, due to small leaf area, perhaps makes this the best vegetation cover to lose (Givoni, 1991). 'Trees' declined from $11.07 \%$ to 9.19\% of the total cover between 1991 and 2011, which is of concern given the importance of trees for air filtration and climate regulation (Farrugia et al., 2013). Evapotranspiration in vegetated front gardens reduces the urban heat island effect, which is caused by high quantities of heat absorbing surfaces such as concrete and brick (Farrugia et al., 2013). The importance of evapotranspiration will increase further with climate change set to enhance heat wave likelihood and intensity (Farrugia et al., 2013; Smith et al., 2009). Furthermore, vegetated surfaces alter carbon balances, one study estimating that in a garden $83 \%$ of carbon is soil stored, and $16 \%$ is stored in other vegetation with the remainder in lawns (Jo and McPherson, 1995). Vegetated surfaces provide habitats for flora and fauna, enhancing urban biodiversity (Davies et al.,
2009). Indeed, authors such as Smith et al. (2006) believe that gardens may be the UK's most important nature reserve. If so, the $14.81 \%$ loss in permeable cover in Southampton's front gardens between 1991 and 2011 needs addressing to preserve garden habitats and to retain biodiversity and the ecosystem services provided.

'Gravel' was included as a permeable surface, yet in 2011 it still only accounted for $2.7 \%$ of the total cover. Therefore this section relates primarily to vegetated permeable cover. However, 'gravel' does bring many of the ecosystem services depicted throughout, with the exception of social and cultural services, as the non-cohesive nature of 'gravel' allows infiltration, reducing runoff and providing a surface for flora and fauna habitats (Kowarik, 2011).

Gardens, like all urban green spaces, provide necessary social and cultural benefits to everyday urban life, primarily through the provision of space for physical interaction (Freeman et al., 2012; Smith et al., 2011). Botkin and Beveridge (p. 18, 1997) advocate the importance of urban green space, writing "vegetation is essential to achieving the quality of life that creates a great city and that makes it possible for people to live a reasonable life within an urban environment". Additionally, vegetated front gardens can absorb noise, for example from the nearby road network (London Assembly Environment Committee, 2005), potentially reducing noise levels by $3 \mathrm{dBA}$ compared to a concrete surface (Kihlman, 1993).

Although there are numerous ecosystem services provided by permeable surfaces, it is important to note that there are also disservices, such as the use of garden chemicals, the use of water for maintenance, the presence of non-native and pest flora and fauna species, and the risk of injury from garden maintenance. However, these are outweighed by the positives and with the proportion of permeable front gardens expected to reduce further, the ecosystem services they provide will also reduce, hence there is a growing need for policy and legislation to prevent the decline.

\subsection{Application for policy and legislation}

Front gardens are an important aspect of people's lives for various reasons, from a connection with nature to parking provision. Garden permeability change occurs irrespective of the size of gardens, which varies between $\sim 3.6$ and $\sim 2290 \mathrm{~m}^{2}$ (Loram et al., 2007). Front gardens are more prone to be changed given road network access and thus are more prone to be converted to facilitate parking (Perry and Nawaz, 2008). Therefore with impermeable change occurring on scales up to $\sim 2290 \mathrm{~m}^{2}$ per garden (Loram et al., 2007), it is strange, and of great concern, that national and local policy makers have little or no control (Verbeeck et al., 2011).

Some policy and legislation, as summarised in the introduction, have had an influence on garden permeability. However, even today, gardens have no special status in planning law other than as a private amenity space (Department for Communities and Local Government, 2010; Sayce et al., 2012). Moreover, the policy and legislation in place have had varying degrees of success. UK Planning Policy Statement 3 (PPS 3 ) for example was considered unsuccessful in conserving permeable garden space in two out of three LAs surveyed (Department for Communities and Local Government, 2010). The 2008 amendment to the Town and Country Planning (General Permitted Development) Order (1995) can be criticised because it does not specify the size of the permeable surface required within the curtilage for runoff provision, and hence this could simply entail a small shrubbery which is unlikely to alleviate flooding vulnerability. On the other hand the $5 \mathrm{~m}^{2}$ limit of the Order that can be viewed positively as the average parking space is typically more than twice this size, and as such it helps to prevent parking provision, reported to be the main reason for impermeable change (Perry and Nawaz, 2008). Several LAs have reported that the Order has been useful when defending refusal decisions and thus the Order had potentially helped reduce the need for flood regulation (Sayce et al., 2012). 
Policy and legislation have also been created to ensure that LAs address flooding problems and provide flood regulation. Much of the policy and legislation was formulated after the severe floods across the UK in 2007. Initially the UK Planning Policy Statement 25 (PPS 25) was created in 2008, stating that LAs should complete Strategic Flood Risk Assessments. Later the Floods and Water Management Act 2010, required SWMPs to be completed by LAs, to encourage local partnerships to work together in flood regulation, which is highly important given that no overriding body is responsible for surface water drainage (SCC, 2011).

Despite this policy and legislation, there still appears to be a lack of local guidance and policy to prevent change to impermeable front garden cover. Sayce et al. (2012) suggested that the lack of guidance was due to the fragmented and sporadic nature of garden change which makes it difficult to monitor. However, with more impermeable front gardens, engineering works, including drainage network improvements and installation techniques which promote infiltration, will be needed to increase the attenuation storage volumes within drainage basins in the future (Ellis and D'Archy, 2002). These engineering solutions would be more costly than the greater provision and implementation of policy and legislation.

In order to ensure improved policy and legislation, policy makers need to increase awareness of the consequence of permeability changes. This can only be done through research like this study. The need for more research is supported by Mathieu et al. (2007) who stated that gardens are one of the least studied urban environment habitats. Further research to improve the understanding of the ecosystem services provided by permeable front gardens would increase their importance in major cities such as Southampton, and hopefully prevent their destruction. The need for an overall improvement in research and education has also been stated by Gaston et al. (2005), the London Assembly Environment Committee (2005) and Perry and Nawaz (2008), without which the creation of appropriate policy and legislation to prevent the increasing loss of permeable domestic front gardens will not be possible.

\section{Conclusion}

We have revealed a $22.47 \%$ increase in impermeable domestic front garden cover, and an average required increase of $26.23 \%$ in attenuation storage volumes across Southampton's high-risk flooding hotspots between 1991 and 2011. These increases have negative implications for ecosystem services, especially with regard to flood regulation. Domestic front gardens as a component of urban green space contribute to human well-being and reduce environmental risk, and should be subject to increased recognition by local and national planners and political decision makers. With urbanisation, population growth and climate change set to continue, careful management is needed to prevent further permeable domestic front garden loss, to ensure that they continue to provide a diversity of ecosystem services inclusive of flood regulation.

\section{Conflict of interest}

We (the authors) have no actual or potential conflict of interest, including any financial, personal or other relationships with other people or organisations within three years of beginning the submitted work that could inappropriately influence, or be perceived to influence, our work.

\section{References}

Bernatzky A. The effects of trees on the urban climate. Trees in the 21st century - based on the first International Arbocultural Conference. Berkhamster: Academic Publishers; 1983. p. 59-76.

Bird SL, Exum LR, Alberty SW. Generating high quality impervious cover data. Qual Assur 2000;8:91-103.
Boardman S. Soil erosion and flooding on the eastern South Downs, southern England 1976-2001. Trans Inst Brit Geogr 2003;28:176-96.

Botkin DB, Beveridge CE. Cities as environments. Urban Ecosyst 1997;1:3-19.

Cameron RW, Blanuša T, Taylor JE, Salisbury A, Halstead AJ, Henricot B, et al. The domestic garden - its contribution to urban green infrastructure. Urban For Urban Green 2012;11:129-37.

Colding J, Lundberg J, Folke C. Incorporating green-area user groups in urban ecosystem management. Ambio 2006:35:237-44.

Davies ZG, Fuller RA, Loram A, Irvine KN, Sims V, Gaston J. A national scale inventory of resource provision for biodiversity within domestic gardens. Biol Conserv 2009; 142:761-71.

Davies L, Batty M, Beck H, Brett H, Gaston KJ, Harris J, et al. Chapter 10, urban broad habitat. UK National Ecosystem Assessment. UK: Defra; 2011.

Deletic AB, Maksimovic CT. Evaluation of water quality factors in storm runoff from paved areas. J Environ Eng ASCE 1998;124:869-79.

Department for Communities and Local Government. Garden developments: understanding the issues. London: Department for Communities and Local Government; 2010.

Department for Transport. Transport statistics Great Britain: 2011. London: Department for Transport; 2011.

Dunse N, Sotirios Thanosa S, Bramleya G. Planning policy, housing density and consumer preferences. J Prop Res 2013;30:221-38.

Ellis JB, D'Archy BJ. Sustainable urban-drainage systems and catchment planning. Water Environ J 2002;16:286-91.

European Commission. Directive 2000/60/EC of the European Parliament and of the Council of 23 October 2000 establishing a framework for Community action in the field of water policy. Official Journal of the European Communities L 2000;327:1-72.

Farrugia S, Hudson MD, McCulloch L. An evaluation of flood control and urban cooling ecosystem services delivered by urban green infrastructure. Int J Biodivers Sci Ecosyst Serv Manage 2013:9:136-45.

Flood Risk Regulations. UK Statutory Instrument No 3042; 2009.

Flood and Water Management Act. Available at http://www.legislation.gov.uk/ukpga/ 2010/29/contents, 2010.

Freeman C, Dickinson KJ, Porter S, van Heezik Y. "My garden is an expression of me": exploring householders' relationships with their gardens. J Environ Psychol 2012;32: 135-43.

Gaston KJ, Warren PH, Thompson K, Smith RM. Urban domestic gardens (IV): the extent of the resource and its associated features. Biodivers Conserv 2005;14:3327-49.

Givoni B. Impact of planted areas on urban environmental quality: a review. Atmos Environ B 1991;25:289-99.

Goddard MA, Dougill AJ, Benton TG. Scaling up from gardens: biodiversity conservation in urban environments. Trends Ecol Evol 2010;25:90-8.

Gupta K, Kumar P, Pathan SK, Sharma KP. Urban Neighborhood Green Index - a measure of green spaces in urban areas. Landsc. Urban Plan 2012;105:325-35.

Healey P. Hard surfacing of front gardens: report on desk research for the Borough of Ealing. Middlesex: Pene Healey Associates; 2004.

Hollis GE. The effect of urbanisation on floods of different recurrence. Water Resour Res 1975;11:431-5.

Jim CY, Chen WY. Perception and attitude of residents towards urban green spaces in Guangzhou (China). Environ Manage 2006;38:338-49.

Jo HK, McPherson EG. Carbon storage and flux in urban residential green space. J Environ Manage 1995;45:109-33.

Kaźmierczak A, Cavan G. Surface water flooding risk to urban communities: analysis of vulnerability, hazard and exposure. Land use Urban Plan 2011;103:185-97.

Kellagher R. Preliminary rainfall runoff management for developments. Environment Agency: Bristol; 2012.

Kihlman T. National action plan against noise. Allmänna Förlaget: Stockholm; 1993.

Kowarik I. Novel urban ecosystems, biodiversity, and conservation. Environ Pollut 2011; 159:1974-83.

Leibling D. Car ownership in Great Britain. London: RAC Foundation; 2008.

London Assembly Environment Committee. Crazy paving: the environmental importance of London's front gardens. London: Greater London Authority; 2005.

Loram A, Tratalos J, Warren PH, Gaston KJ. Urban domestic gardens (X): the extent \& structure of the resource in five major cities. Landsc Ecol 2007;22:601-15.

Mathieu R, Freeman C, Aryal J. Mapping private gardens in urban areas using objectoriented techniques and very high-resolution satellite imagery. Landsc Urban Plan 2007;81:179-92.

Millennium Ecosystem Assessment. Ecosystem and human well-being: synthesis Washington: Island Press; 2005.

Pauleit S, Duhme F. Assessing the environmental performance of land cover. Landsc Urban Plan 2000;52:1-20.

Pauleit S, Ennos R, Golding Y. Modelling the environmental impacts of urban land use and land cover change: a study in Merseyside, UK. Landsc Urban Plan 2005; 71:295-310.

Penning-Rowsell E. Flooding and planning: conflict and confusion. Town Country Plann 2001;70:108-10.

Perry T, Nawaz NR. An Investigation into the extent and impacts of hard-surfacing of domestic gardens in an area of Leeds, United Kingdom. Landsc Urban Plan 2008;86 $1-13$.

Royal Horticultural Society. Front gardens. London: Royal Horticultural Society; 2006.

Sayce S, Walford N, Garside P. Residential development on gardens in England: their role in providing sustainable housing supply. Land Use Policy 2012;29:771-80.

SCC (Southampton City Council). Southampton Surface Water Management Plan. East Grinstead: Capita Symonds; 2011.

SCC (Southampton City Council). Parks and green spaces. 2013. [Online, Available at: https:// www.southampton.gov.uk/s-leisure/parksgreenspaces/, Accessed 0903 2013]

Smith C. London: a garden city? London: London Wildlife Trust; 2010. 
Smith RM, Gaston KJ, Warren PH, Thompson K. Urban domestic gardens (VIII): environmental correlates of invertebrate abundance. Biodivers Conserv 2006;15:2515-45.

Smith JB, Schneider SH, Oppenheimer M, Yohe GW, Hare W, Mastrandrea MD, et al Assessing dangerous climate change through an update of the Intergovernmenta Panel on Climate Change (IPCC); reasons for concern. Proc Natl Acad Sci U S A 2009; $106: 4133-7$

Smith C, Dawson D, Archer J, Davies M, Frith M, Hughes E, et al. From green to grey; observed changes in garden vegetation structure in London, 1998-2008. London: London Wildlife Trust; 2011.
Swan A. How increased urbanisation has induced flooding problems in the UK: a lesson for African cities? Phys Chem Earth 2010;35:643-7.

Verbeeck K, Van Orshoven J, Hermy M. Measuring extent, location and change of imperviousness in urban domestic gardens in collective housing projects. Landsc Urban Plan 2011;100:57-66. 